\title{
Endogenous Hydrogen Peroxide Regulates the Excitability of Midbrain Dopamine Neurons via ATP-Sensitive Potassium Channels
}

\author{
Marat V. Avshalumov, ${ }^{1}$ Billy T. Chen, ${ }^{1}$ Tibor Koós, ${ }^{2}$ James M. Tepper, ${ }^{2}$ and Margaret E. Rice ${ }^{1}$ \\ ${ }^{1}$ Department of Neurosurgery and Department of Physiology and Neuroscience, New York University School of Medicine, New York, New York 10016, and \\ ${ }^{2}$ Center for Molecular and Behavioral Neuroscience, Rutgers, The State University of New Jersey, Newark, New Jersey 07102
}

\begin{abstract}
ATP-sensitive $\mathrm{K}^{+}\left(\mathrm{K}_{\mathrm{ATP}}\right)$ channels link metabolic state to cell excitability. Here, we examined regulation of $\mathrm{K}_{\mathrm{ATP}}$ channels in substantia nigra dopamine neurons by hydrogen peroxide $\left(\mathrm{H}_{2} \mathrm{O}_{2}\right)$, which is produced in all cells during aerobic metabolism. Blockade of $\mathrm{K}_{\mathrm{ATP}}$ channels by glibenclamide $(100 \mathrm{~nm})$ or depletion of intracellular $\mathrm{H}_{2} \mathrm{O}_{2}$ by including catalase, a peroxidase enzyme, in the patch pipette increased the spontaneous firing rate of all dopamine neurons tested in guinea pig midbrain slices. Using fluorescence imaging with dichlorofluorescein to visualize intracellular $\mathrm{H}_{2} \mathrm{O}_{2}$, we found that moderate increases in $\mathrm{H}_{2} \mathrm{O}_{2}$ during partial inhibition of glutathione (GSH) peroxidase by mercaptosuccinate $(0.1-0.3 \mathrm{~mm})$ had no effect on dopamine neuron firing rate. However, with greater GSH inhibition (1 mM mercaptosuccinate) or application of exogenous $\mathrm{H}_{2} \mathrm{O}_{2}, 50 \%$ of recorded cells showed $\mathrm{K}_{\mathrm{ATP}}$ channel-dependent hyperpolarization. Responsive cells also hyperpolarized with diazoxide, a selective opener for $\mathrm{K}_{\mathrm{ATP}}$ channels containing sulfonylurea receptor SUR1 subunits, but not with cromakalim, a selective opener for SUR2-based channels, indicating that SUR1-based $\mathrm{K}_{\mathrm{ATP}}$ channels conveyed enhanced sensitivity to elevated $\mathrm{H}_{2} \mathrm{O}_{2}$. In contrast, when endogenous $\mathrm{H}_{2} \mathrm{O}_{2}$ levels were increased after inhibition of catalase, the predominant peroxidase in the substantia nigra, with 3-amino-1,2,4-triazole $(1 \mathrm{~mm})$, all dopamine neurons responded with glibenclamidereversible hyperpolarization. Fluorescence imaging of $\mathrm{H}_{2} \mathrm{O}_{2}$ indicated that catalase inhibition rapidly amplified intracellular $\mathrm{H}_{2} \mathrm{O}_{2}$, whereas inhibition of GSH peroxidase, a predominantly glial enzyme, caused a slower, smaller increase, especially in nonresponsive cells. Thus, endogenous $\mathrm{H}_{2} \mathrm{O}_{2}$ modulates neuronal activity via $\mathrm{K}_{\text {ATP }}$ channel opening, thereby enhancing the reciprocal relationship between metabolism and excitability.
\end{abstract}

Key words: basal ganglia; DCF fluorescence imaging; dopamine; $\mathrm{K}_{\mathrm{ATP}}$ channels; Parkinson's disease; peroxide; potassium $\left(\mathrm{K}^{+}\right)$channels; substantia nigra

\section{Introduction}

ATP-sensitive $\mathrm{K}^{+}\left(\mathrm{K}_{\mathrm{ATP}}\right)$ channels are multimeric proteins composed of inwardly rectifying pore-forming subunits (typically $\mathrm{K}_{\mathrm{ir}} 6.2$ in neurons) and regulatory, sulfonylurea receptor subunits (SUR1/SUR2) (Inagaki et al., 1996; Ashcroft and Gribble, 1998; Babenko et al., 1998). $K_{\text {ATP }}$ channel opening causes membrane hyperpolarization, which lowers cell activity and energy consumption, thereby linking metabolic state to excitability (Noma, 1983; Ashcroft and Ashcroft, 1990). The highest levels of $\mathrm{K}_{\mathrm{ATP}}$ channels in the CNS are found in the substantia nigra (SN) and striatum (Mourre et al., 1989; Xia and Haddad, 1991; Zini et al.,

\footnotetext{
Received Nov. 16, 2004; revised March 16, 2005; accepted March 16, 2005.

This work was supported by National Institutes of Health-National Institute of Neurological Disorders and Stroke Grants NS-36362 and NS-45325 and by the National Parkinson Foundation (M.E.R.). We are grateful to Dr. Paul Witkovsky for assistance with immunocytochemistry and to Abram Akopian for advice about whole-cell recording

Correspondence should be addressed to Dr. Margaret E. Rice, Department of Physiology and Neuroscience, New York University School of Medicine, 550 First Avenue, New York, NY 10016. E-mail: margaret.rice@nyu.edu.

B. T. Chen's present address: Ernest Gallo Clinic and Research Center, Department of Neurology, University of California, San Francisco, 5858 Horton Street, Suite 200, Emeryville, CA 94608.

T. Koós' present address: Department of Neurobiology, Yale University School of Medicine, 333 Cedar Street, New Haven, СT 06520 .

DOI:10.1523/JNEUROSCI.4701-04.2005

Copyright $\odot 2005$ Society for Neuroscience $\quad$ 0270-6474/05/254222-10\$15.00/0
}

1993), which are key structures of the basal ganglia required for movement (Dahlstrom and Fuxe, 1964; Albin et al., 1989; Olanow and Tatton, 1999; Prensa and Parent, 2001).

The prominent expression of $\mathrm{K}_{\mathrm{ATP}}$ channels in dopamine (DA) cells of the $\mathrm{SN}$ pars compacta $(\mathrm{SNc})$ suggests a potential role in governing nigrostriatal excitability, yet the function and regulation of these channels are poorly understood. Although $\mathrm{K}_{\mathrm{ATP}}$ channel opening in DA neurons of the SNc can accompany hypoxia (Jiang et al., 1994; Mercuri et al., 1994; Guatteo et al., 1998) or metabolic suppression (Jiang et al., 1994; Liss et al., 1999), interpretation of reported data has been hindered by variable cell responses. Multiple populations of DA cells (Murphy and Greenfield, 1992; Liss et al., 1999) and/or novel $\mathrm{K}_{\mathrm{ATP}}$ channel subtypes (Jiang et al., 1994) have been proposed to reconcile conflicting findings.

The primary factor thought to govern $\mathrm{K}_{\mathrm{ATP}}$ channel opening is ATP/ADP ratio (Noma, 1983; Cook and Hales, 1984; Ashcroft and Ashcroft, 1990; Ashcroft and Gribble, 1998). Glucose, by regulating ATP levels, is an indirect modulator of these channels; glucose-dependent $\mathrm{K}_{\mathrm{ATP}}$ channel regulation underlies insulin secretion in pancreatic $\beta$-cells (Cook and Hales, 1984; Ashcroft and Ashcroft, 1990) and GABA release in the SN (Amoroso et al., 
1990). More recently, hydrogen peroxide $\left(\mathrm{H}_{2} \mathrm{O}_{2}\right)$ has been shown to regulate $\mathrm{K}_{\mathrm{ATP}}$ channel activity (Ichinari et al., 1996; Tokube et al., 1998; Krippeit-Drews et al., 1999; Avshalumov and Rice, 2003; Avshalumov et al., 2003). In $\beta$-cells, exogenous $\mathrm{H}_{2} \mathrm{O}_{2}$ causes sulfonylurea-sensitive hyperpolarization and suppression of insulin release (Krippeit-Drews et al., 1999). Moreover, endogenous $\mathrm{H}_{2} \mathrm{O}_{2}$ generated downstream from AMPA receptor activation in the striatum suppresses axonal DA release via SUR1-based $\mathrm{K}_{\mathrm{ATP}}$ channels (Avshalumov and Rice, 2003; Avshalumov et al., 2003); endogenous $\mathrm{H}_{2} \mathrm{O}_{2}$ also suppresses somatodendritic DA release in the SNc (Chen et al., 2002), although a role for $\mathrm{K}_{\mathrm{ATP}}$ channels has not been examined.

Regulation of $\mathrm{K}_{\mathrm{ATP}}$ channels in DA neurons by $\mathrm{H}_{2} \mathrm{O}_{2}$ would provide a mechanism to reconcile previous conflicting results in the literature: $\mathrm{H}_{2} \mathrm{O}_{2}$ is generated in all cells by mitochondrial respiration (Boveris and Chance, 1973; Dugan et al., 1995; Liu et al., 2002) and is therefore well suited to serve as a signaling agent (besides ATP) to link excitability to energy demands. Here, we used whole-cell recording coupled with fluorescence imaging to examine the physiological role of $\mathrm{H}_{2} \mathrm{O}_{2}$ and $\mathrm{K}_{\mathrm{ATP}}$ channels in SNc DA neurons. The data indicate that endogenous $\mathrm{H}_{2} \mathrm{O}_{2}$ acts in a graded manner to regulate tonic DA cell activity and responsiveness to oxidative challenge via $\mathrm{K}_{\mathrm{ATP}}$ channels.

\section{Materials and Methods}

Brain slice preparation. Animal-handling procedures were in accordance with National Institutes of Health guidelines and were approved by the New York University School of Medicine Animal Care and Use Committee. The procedure for preparing midbrain slices for whole-cell recording was similar to that described by Koós and Tepper (1999). Young adult guinea pigs (male; Hartley; 150-250 g) were deeply anesthetized with 40 $\mathrm{mg} / \mathrm{kg}$ pentobarbital (intraperitoneally) and perfused transcardially with $\sim 30 \mathrm{ml}$ of nearly frozen $\left(\sim 0^{\circ} \mathrm{C}\right)$ modified artificial CSF (ACSF) at a rate of $\sim 10 \mathrm{ml} / \mathrm{min}$. This solution contained the following (in $\mathrm{mm}$ ): 225 sucrose, $2.5 \mathrm{KCl}, 0.5 \mathrm{CaCl}_{2}, 7 \mathrm{MgCl}_{2}, 28 \mathrm{NaHCO}_{3}, 1.25 \mathrm{NaH}_{2} \mathrm{PO}_{4}, 7$ glucose, 1 ascorbate, and 3 pyruvate. After perfusion, the brain was removed into ice-cold modified ACSF for 1-2 min. Midbrain containing the SNc was blocked and fixed to the stage of a vibratome (Ted Pella, St. Louis, MO) for slicing. Slices $(300 \mu \mathrm{m})$ were maintained initially at $34^{\circ} \mathrm{C}$ for $30 \mathrm{~min}$ in medium (in mM: $125 \mathrm{NaCl}, 2.5 \mathrm{KCl}, 2 \mathrm{CaCl}_{2}, 1 \mathrm{MgCl}_{2}, 25$ $\mathrm{NaHCO}_{3}, 1.25 \mathrm{NaH}_{2} \mathrm{PO}_{4}, 25$ glucose, 1 ascorbate, and 3 pyruvate, $\mathrm{pH}$ 7.3-7.4, equilibrated with $95 \% \mathrm{O}_{2} / 5 \% \mathrm{CO}_{2}$ ) and then allowed to cool to room temperature for at least $30 \mathrm{~min}$. For experiments, slices were transferred to a submersion chamber at $32^{\circ} \mathrm{C}$ and superfused at $1.2 \mathrm{ml} / \mathrm{min}$ with recording ACSF containing the following (in $\mathrm{mM}$ ): $124 \mathrm{NaCl}, 3.7$ $\mathrm{KCl}, 26 \mathrm{NaHCO}_{3}, 2.4 \mathrm{CaCl}_{2}, 1.3 \mathrm{MgSO}_{4}, 1.3 \mathrm{KH}_{2} \mathrm{PO}_{4}$, and 10 glucose, equilibrated with $95 \% \mathrm{O}_{2} / 5 \% \mathrm{CO}_{2}$ (Avshalumov et al., 2003).

Visualized whole-cell recording. Neurons of the SNc were visualized under infrared-differential interference contrast microscopy using an Olympus BX51WI fixed-stage microscope (New York/New Jersey Scientific, Middlebush, NJ) with a $40 \times$ water immersion objective; in imaging studies, a Pro-Scan $11 z$-axis controller (Prior Scientific, Rockland, MA) was used to sharpen focus. Whole-cell recordings were obtained with patch pipettes pulled from $1.5 \mathrm{~mm}$ outer diameter/0.86 mm inner diameter borosilicate glass (Sutter Instruments, Novato, CA) on a Flaming/ Brown model P-97 patch pipette puller (Sutter Instruments). Pipettes had open-tip diameters of $<2 \mu \mathrm{m}$ and resistances of 5-7 M $\Omega$. The intracellular filling solution contained the following (in $\mathrm{mM}$ ): 120 K-gluconate, $20 \mathrm{KCl}, 2 \mathrm{MgCl}, 10 \mathrm{Na}$-HEPES, 10 EGTA, $3 \mathrm{Na}_{2}$-ATP, and 0.2 GTP, pH adjusted to 7.2-7.3 with KOH, 280-290 mOsm (Koós and Tepper, 1999; Paladini et al., 1999). In some experiments, the internal solution also contained Lucifer yellow $(0.1 \%)$, Alexa Red $(0.1 \%)$ plus $2^{\prime}, 7^{\prime}$-dichlorodihydrofluorescein $\left(\mathrm{H}_{2} \mathrm{DCF}\right)$ diacetate $\left(\mathrm{H}_{2} \mathrm{DCFDA}\right)$ (7 $\mu \mathrm{M})$, or catalase [500 international units $(\mathrm{IU}) / \mathrm{ml}$ ]. Amphotericin $\mathrm{B}$ (240-300 $\mu \mathrm{g} / \mathrm{ml}$ of backfill solution) was used for perforated-patch recordings (Rae et al., 1991); the electrode tip was filled with normal intra- cellular solution lacking amphotericin B. After gigaseal formation, the patch was monitored until action potential amplitudes were stable (15-25 min); Alexa Red was included in the backfill solution to indicate that the perforation remained intact.

Cell input resistance was calculated from the current-voltage plot of a family of hyperpolarizing current pulses; measurements were taken 100 $\mathrm{ms}$ after pulse onset at the same membrane potential $(-91 \mathrm{mV})$ for each neuron under control and experimental conditions. Whole-cell recording data were acquired using an Axopatch 200B amplifier and Digidata board 1322A controlled by Clampex 9.0 and analyzed using ClampFit (Axon Instruments, Union City, CA); liquid junction potential correction $(9.4 \mathrm{mV})$ was calculated using Clampex.

$\mathrm{H}_{2} \mathrm{O}_{2}$ imaging. To image intracellular $\mathrm{H}_{2} \mathrm{O}_{2}$, the $\mathrm{H}_{2} \mathrm{O}_{2}$-selective fluorescent dye $\mathrm{H}_{2}$ DCFDA (Molecular Probes, Eugene, $\mathrm{OR}$ ) was loaded into a given cell via the patch pipette used for simultaneous physiological recording. This dye is cleaved by intracellular esterases to form $\mathrm{H}_{2} \mathrm{DCF}$, which becomes fluorescent dichlorofluorescein (DCF) after oxidation by primary intracellular peroxides (Reynolds and Hastings, 1995; Sah and Schwartz-Bloom, 1999). Once a seal was obtained, cells were held for 15-20 min before images were taken to allow time for diffusion of the dye into the cell (confirmed by visualization of Alexa Red) and esterase cleavage to form DCF. Data were acquired with an illuminator, a monochrometer, and an IC-200 (see Figs. 2, 5) or a Cascade 512 (see Fig. 8) camera obtained from Photon Technology International (Lawrenceville, NJ) and analyzed using Image Master software (Photon Technology International). The excitation wavelength for DCF was $488 \mathrm{~nm}$, with fluorescence emission at $535 \mathrm{~nm}$. To minimize DCF photo-oxidation, illumination was limited to $30 \mathrm{~ms}$ at $500 \mathrm{~ms}$ intervals; images were acquired using eight-frame averaging. A background image was taken from each cell before DCF infiltration; this background was subtracted from each averaged image for a given cell in subsequent data analysis. Fluorescence intensity in background-subtracted frame averages was normalized and illustrated as $[($ intensity - basal $) /($ basal $)] \times 100 \%$.

Immunocytochemistry. To confirm DA cell identity, cells were double labeled with Lucifer yellow and a fluorescence-labeled antibody to tyrosine hydroxylase (TH). Presumed DA cells were filled with Lucifer yellow during recording. Slices were then fixed for $1 \mathrm{~h}$ in $4 \%$ paraformaldehyde in phosphate buffer $\left(50 \mathrm{~mm} \mathrm{NaH} \mathrm{PO}_{4}\right.$ and $100 \mathrm{~mm} \mathrm{NaCl}, \mathrm{pH}$ 7.4), washed, and processed for TH immunoreactivity at room temperature (Rice et al., 1997; Witkovsky et al., 2000). The primary antibody was a monoclonal mouse anti-TH (Chemicon, Temecula, CA), and the secondary antibody was Texas Red-conjugated rabbit anti-mouse fluorescein isothiocyanate (Jackson ImmunoResearch, West Grove, PA). Fixed and stained whole slices were mounted in Vectashield medium (Vector Laboratories, Burlingame, CA) and viewed using a D-Eclipse confocal microscope (Nikon, Melville, NY).

Chemicals and statistical analysis. Glibenclamide, tolbutamide, $\mathrm{H}_{2} \mathrm{O}_{2}$, mercaptosuccinate (MCS), 3-amino-1,2,4-triazole (ATZ), tetrodotoxin (TTX), Lucifer yellow, amphotericin B, and components of all intracellular and extracellular media were obtained from Sigma (St. Louis, MO); Alexa Red and $\mathrm{H}_{2}$ DCFDA were obtained from Molecular Probes; and catalase (bovine liver) was obtained from Calbiochem (San Diego, CA). Stock solutions of glibenclamide, amphotericin $\mathrm{B}$, and $\mathrm{H}_{2}$ DCFDA were made in dimethylsulfoxide (DMSO) (final DMSO concentration in ACSF or backfill solution was $0.01 \%$ ). Control data for these agents were obtained with $0.01 \%$ DMSO, which had no effect on the physiological properties of DA cells. Data are given as means \pm SEM $(n=$ number of cells). Significance of differences $(p<0.05)$ was assessed using unpaired Student's $t$ test or one-way ANOVA.

\section{Results}

\section{Identification of DA neurons}

DA neurons in slices of guinea pig SNc exhibited characteristic pacemaker activity, with an average firing frequency of $3.0 \pm 0.3$ $\mathrm{Hz}(n=83)$ (Fig. $1 a)$, a relatively long action potential duration $(2.6 \pm 0.2 \mathrm{~ms} ; n=83)$, and a mean input resistance of $192 \pm 16$ $\mathrm{M} \Omega(n=83)$. Additionally, during hyperpolarizing current injection, all recorded neurons showed a prominent sag in mem- 


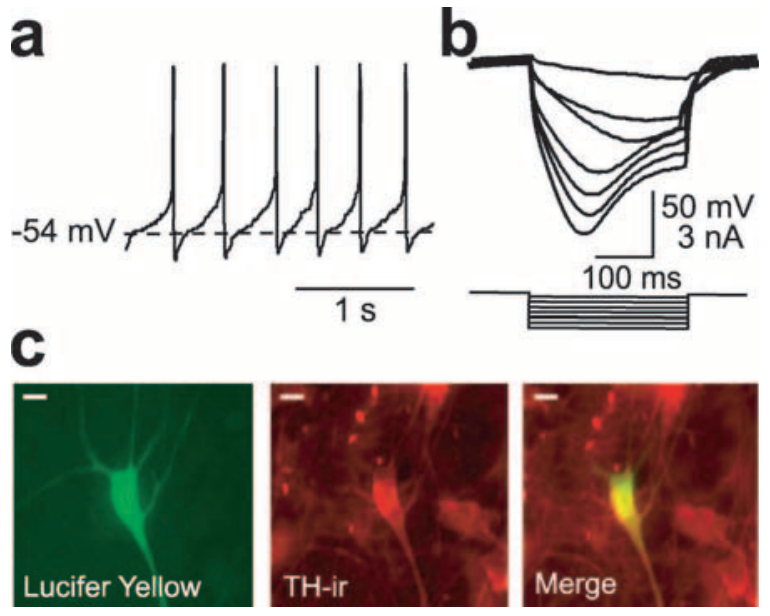

Figure 1. Identification of DA neurons. $\boldsymbol{a}$, Representative current-clamp record from a neuron in the SNc showing spontaneous "pacemaker" firing activity. $\boldsymbol{b}$, Voltage responses to hyperpolarizing current injection in this cell; note the prominent time-dependent rectification (sag). c, This cell was filled with Lucifer yellow during recording (left), and then the slice was processed for TH immunochemistry (TH-ir; middle). Double labeling (right) confirmed that the recorded cell was a DA neuron. Scale bars, $20 \mu \mathrm{m}$.

brane potential (Fig. $1 b$ ). These properties are similar to those reported previously for DA neurons in vitro (Grace and Onn, 1989; Yung et al., 1991; Jiang et al., 1994; Paladini et al., 1999). Cells exhibiting DA cell-like electrophysiological characteristics were also positive for TH immunoreactivity (Fig. 1c), confirming that these were DA neurons (Grace and Onn, 1989; Yung et al., 1991).

$\mathrm{K}_{\mathrm{ATP}}$ channels and $\mathrm{H}_{2} \mathrm{O}_{2}$ regulate spontaneous firing rate To examine basal and activity-dependent $\mathrm{H}_{2} \mathrm{O}_{2}$ generation in DA neurons, we monitored intracellular $\mathrm{H}_{2} \mathrm{O}_{2}$ using DCF. Basal DCF fluorescence was detected in all DA neurons (Fig. $2 a$, bottom), indicating tonic $\mathrm{H}_{2} \mathrm{O}_{2}$ generation during normal pacemaker activity. To confirm activity-dependent $\mathrm{H}_{2} \mathrm{O}_{2}$ generation in DA neurons, we increased the cell firing rate by injecting depolarizing current $(0.2 \mathrm{nA}, 350 \mathrm{~ms})$. This caused an increase in mean spike frequency to $32 \pm 6 \mathrm{~Hz}(n=17)$ (Fig. $2 a$, top). After a few spikes, DCF fluorescence began to rise, reaching a maximum change of $27 \pm 2 \%(n=17 ; p<0.01$ vs basal fluorescence) shortly after the pulse ended (Fig. $2 a$, bottom).

We then examined whether $\mathrm{H}_{2} \mathrm{O}_{2}$-sensitive $\mathrm{K}_{\text {ATP }}$ channels contributed to resting membrane properties under basal conditions. With conventional whole-cell recording, glibenclamide (3 $\mu \mathrm{M}$ ), a $\mathrm{K}_{\mathrm{ATP}}$ channel blocker, caused a significant, $60 \%$ increase in mean firing frequency (from $3.0 \pm 0.3$ to $4.8 \pm 0.2 \mathrm{~Hz} ; n=19$; $p<0.001)$ in all cells tested, accompanied by a small but significant membrane depolarization $(+2.5 \mathrm{mV} ; n=19 ; p<0.01)$ but no change in input resistance (control, $194 \pm 18 \mathrm{M} \Omega$; glibenclamide, $243 \pm 28 \mathrm{M} \Omega ; n=19 ; p>0.05$ ). Similar results were obtained with amphotericin B perforated-patch-clamp recording, which prevents dialysis of intracellular fluid (Rae et al., 1991). The basal firing rate was slightly lower with perforated-patch versus conventional whole-cell recording; nonetheless, glibenclamide again caused a $61 \%$ increase in the firing rate (from $2.3 \pm$ 0.1 to $3.7 \pm 0.2 \mathrm{~Hz} ; n=5 ; p<0.01)$.

Although these data implicated $\mathrm{K}_{\mathrm{ATP}}$ channels, previous studies in other cell types indicate that glibenclamide can also block other $\mathrm{K}^{+}$channels, albeit at higher concentrations $(10-87 \mu \mathrm{M})$ than those found to be effective here (Crepel et al., 1993; Schaffer
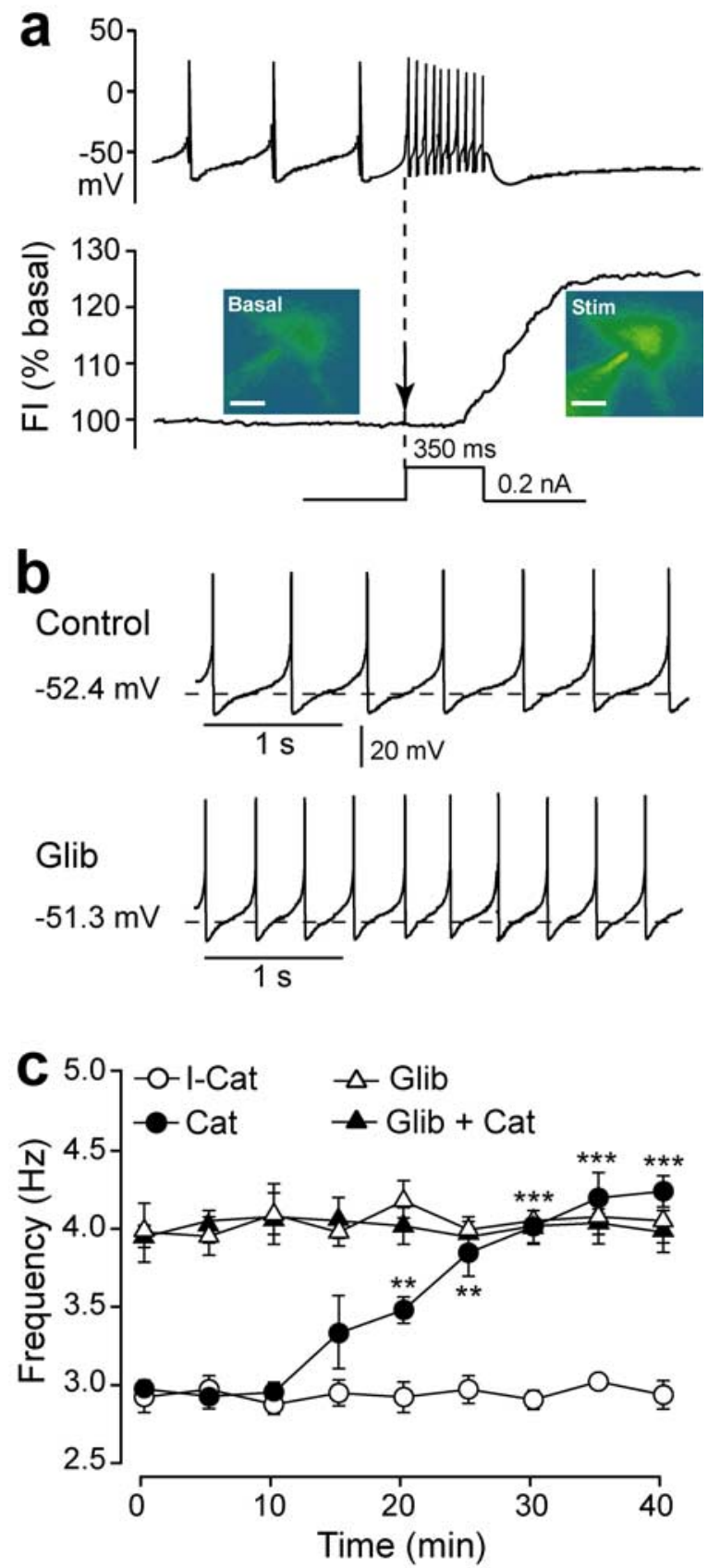

Figure 2. Regulation of spontaneous activity in DA cells by $\mathrm{H}_{2} \mathrm{O}_{2}$ and $\mathrm{K}_{\text {ATP }}$ channels. $\boldsymbol{a}$, In all DA neurons tested ( $n=17$ ), depolarizing current injection ( $0.2 \mathrm{nA}, 350 \mathrm{~ms}$ ) induced an increase in the firing rate (top) that was accompanied by elevated $\mathrm{H}_{2} \mathrm{O}_{2}$ levels [DCF fluorescence intensity (FI); shown as pseudocolored images; $p<0.01$ vs basal $\mathrm{FI}$ (bottom)]. The dashed vertical line and arrow indicate the onset of current injection. Stim, Stimulated. Scale bars, $20 \mu \mathrm{m} . \boldsymbol{b}$, Pacemaker activity in a representative DA neuron under control conditions and after $15 \mathrm{~min}$ in glibenclamide (100 nm; $G$ lib); $K_{\text {ATP }}$ channel blockade by glibenclamide increased the firing rate $(n=5 ; p<0.01)$.c, The firing rate also increased progressively when catalase (Cat; $500 \mathrm{lU} / \mathrm{ml})$ was included in the patch pipette backfill solution $\left[n=7 ;{ }^{* *} p<0.01\right.$ and ${ }^{* * *} p<0.001$ vs respective control frequency after $10 \mathrm{~min}$ of recording (ANOVA)]; heat-inactivated catalase (I-Cat) did not alter spontaneous activity $(n=6)$. Glib (100 nm) applied 15 min before patching prevented the Cat-induced increase in the firing rate $(n=5)$. Data are means \pm SEM.

et al., 1999). We therefore repeated examination of resting membrane properties with $100 \mathrm{~nm}$ glibenclamide, which is specific for $\mathrm{K}_{\text {ATP }}$ channels (Liss et al., 1999). With conventional whole-cell recording, $100 \mathrm{~nm}$ glibenclamide caused a significant $34 \%$ increase in mean firing frequency in all cells tested (from $2.9 \pm 0.1$ 


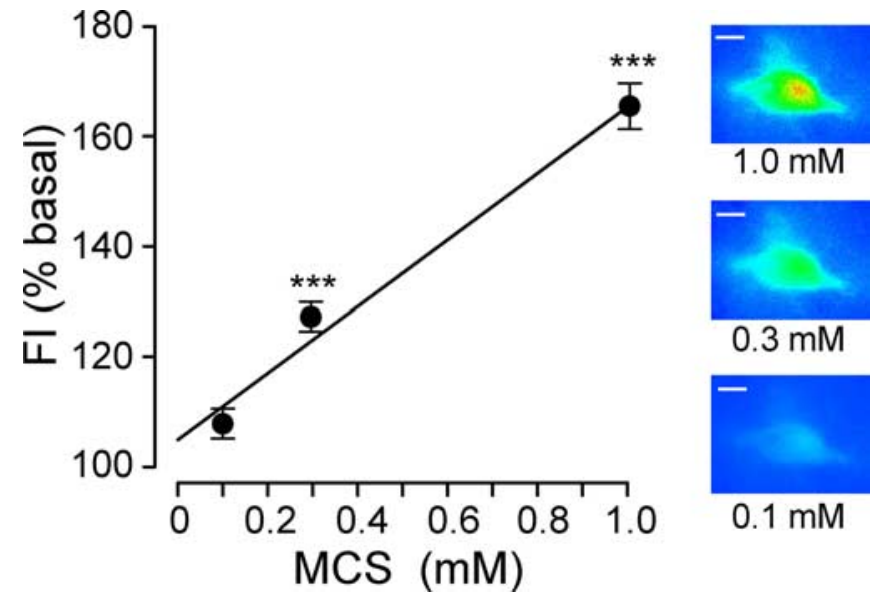

Figure 3. Concentration-dependent effect of GSH peroxidase inhibition by MCS on $\mathrm{H}_{2} \mathrm{O}_{2}$ amplification. Inhibition of GSH peroxidase by MCS (0.1-1 mM) caused a progressive increase in $\mathrm{H}_{2} \mathrm{O}_{2}$ levels [DCF fluorescence intensity ( $\left.\mathrm{FI}\right) ; R^{2}=0.946$ ]. All concentrations were tested in each cell $\left(n=7 ;{ }^{* * *} p<0.001\right.$ vs basal). Images are representative examples of $D C F$ fluorescence for each concentration of MCS tested in one cell. Scale bars, $20 \mu \mathrm{m}$.

to $3.9 \pm 0.1 \mathrm{~Hz} ; n=5 ; p<0.01$ ) (Fig. $2 b, c)$, with no change in membrane potential or input resistance. A comparable $38 \%$ increase (from $2.4 \pm 0.2$ to $3.3 \pm 0.3 \mathrm{~Hz} ; n=5 ; p<0.01$ ) was seen with $100 \mathrm{~nm}$ glibenclamide in perforated-patch-clamp recording. Together, these data confirm a role for $\mathrm{K}_{\mathrm{ATP}}$ channels in the tonic regulation of DA neuron activity.

Inclusion of the $\mathrm{H}_{2} \mathrm{O}_{2}$ metabolizing enzyme catalase (500 IU/ $\mathrm{ml}$ ) in the patch pipette backfill solution caused a similar $38 \%$ increase in DA cell firing rate (Fig. $2 c$ ): pacemaker activity increased progressively from $2.9 \pm 0.2$ to $4.1 \pm 0.1 \mathrm{~Hz}(n=7 ; p<$ 0.001 ) after $40 \mathrm{~min}$ of recording and catalase infiltration into the cells. In contrast, DA neurons recorded with heat-inactivated catalase (Avshalumov et al., 2003) in the pipette showed no change in the firing rate during a similar recording period $(n=6)$ (Fig. 2c). Moreover, catalase had no effect on the spontaneous firing rate when $\mathrm{K}_{\mathrm{ATP}}$ channels were blocked by glibenclamide $(n=5)$ (Fig. $2 c)$, confirming that the effect of catalase was mediated by $\mathrm{H}_{2} \mathrm{O}_{2}$-sensitive $\mathrm{K}_{\text {ATP }}$ channels.

\section{Effect of elevated endogenous $\mathrm{H}_{2} \mathrm{O}_{2}$ on DA neurons \\ Elevation of intracellular $\mathrm{H}_{2} \mathrm{O}_{2}$ during inhibition of glutathione peroxidase}

To examine whether elevated levels of endogenous $\mathrm{H}_{2} \mathrm{O}_{2}$ might also affect DA cell physiology, we used MCS (Dringen et al., 1998) to inhibit glutathione (GSH) peroxidase, which should increase intracellular levels of $\mathrm{H}_{2} \mathrm{O}_{2}$ by decreasing $\mathrm{H}_{2} \mathrm{O}_{2}$ metabolism (Chen et al., 2002; Avshalumov et al., 2003). Changes in DCF fluorescence were used to indicate increases in $\mathrm{H}_{2} \mathrm{O}_{2}$ in response to a range of MCS concentrations applied to a given cell $(n=7)$. A linear increase in DCF fluorescence was seen over an MCS concentration range of $0.1-1 \mathrm{mM}\left(R^{2}=0.946\right)$, with a significant increase for each MCS concentration step $(p<0.001)$ (Fig. 3). Although $0.3 \mathrm{~mm}$ MCS caused a $25 \pm 2 \%$ increase in DCF fluorescence intensity ( $p<0.001$ vs basal), this had no effect on the spontaneous neuron firing rate or membrane potential in any cell tested. Moreover, in three of seven cells, 1 mM MCS was also without effect on DA neuron physiology, despite a mean $65 \pm 3 \%$ increase in fluorescence ( $p<0.001$ vs basal). However, at this MCS concentration, four of seven cells responded with marked hyperpolarization and cessation of firing. These data suggest a concentration threshold for the physiological effects of elevated $\mathrm{H}_{2} \mathrm{O}_{2}$ in responsive cells.
Unfortunately, absolute $\mathrm{H}_{2} \mathrm{O}_{2}$ concentration cannot be determined from a given change in DCF fluorescence intensity, because there are no reliable methods for DCF calibration at the present time. Although we and others (Oyama et al., 1994) have attempted to calibrate DCF with exogenous $\mathrm{H}_{2} \mathrm{O}_{2}$, the nonlinear responses obtained suggests that the dye responds to the number of $\mathrm{H}_{2} \mathrm{O}_{2}$ molecules encountered, rather than concentration per se. Consequently, determination of the $\mathrm{H}_{2} \mathrm{O}_{2}$ concentration threshold must await development of a reliable calibration method for DCF or another $\mathrm{H}_{2} \mathrm{O}_{2}$ sensitive dye.

Physiological effects of elevated intracellular $\mathrm{H}_{2} \mathrm{O}_{2}$ in DA neurons We then examined the effect of GSH peroxidase inhibition by 1 mM MCS on a larger population of DA neurons $(n=38)$ to explore the apparent diversity in DA neuron responsiveness to elevated $\mathrm{H}_{2} \mathrm{O}_{2}$. Again, $1 \mathrm{~mm}$ MCS induced profound membrane hyperpolarization $(13 \pm 3.4 \mathrm{mV} ; n=20 ; p<0.001 \mathrm{MCS}$ vs control) and complete cessation of activity in one population of DA neurons, "responders" (53\%; $n=20$ of 38) (Fig. 4a). The increase in endogenous $\mathrm{H}_{2} \mathrm{O}_{2}$ also caused a decrease in input resistance of $43 \%$ (from $192 \pm 16$ to $113 \pm 18 \mathrm{M} \Omega ; n=20 ; p<$ 0.001 ) accompanied by loss of the sag in membrane potential with hyperpolarizing current injection. These effects reversed after MCS washout (Fig. 4a). A second population of DA cells, "nonresponders" ( $47 \% ; n=18$ of 38$)$, did not respond to MCS application (Fig. $4 d$ ). Thus, two groups of DA cells could be distinguished by their sensitivity to endogenous $\mathrm{H}_{2} \mathrm{O}_{2}$.

In all recorded neurons, $1 \mathrm{~mm}$ MCS caused a consistent increase in intracellular $\mathrm{H}_{2} \mathrm{O}_{2}$, indicated by an $\sim 60 \%$ increase in DCF fluorescence ( $n=14 ; p<0.001$ vs basal) (Figs. $4 b, c, e, f, 5)$. A plateau in DCF fluorescence seen in all cells reflected the irreversible activation of DCF and precluded examination of the time course of $\mathrm{H}_{2} \mathrm{O}_{2}$ clearance after MCS washout. Neither time course nor amplitude of increases in DCF fluorescence differed significantly between responders ( $n=7$ of 14) and nonresponders ( $n=7$ of $14 ; p>0.05$; ANOVA) (Fig. 5 ); physiological data from these cells were included in the data averages above.

To determine whether the MCS-dependent increase in intracellular $\mathrm{H}_{2} \mathrm{O}_{2}$ depended on neuronal activity, we monitored DCF fluorescence when MCS was applied in the presence of TTX (1 $\mu \mathrm{M})$. Application of TTX blocked $\mathrm{Na}^{+}$channel-dependent action potentials but not an underlying pacemaker oscillation in membrane potential ( $n=3$; data not shown), as described previously (Kang and Kitai, 1993; Wilson and Callaway, 2000). In the presence of TTX, $1 \mathrm{~mm}$ MCS did not alter DCF fluorescence $(n=$ 3) (Fig. 5); application of exogenous $\mathrm{H}_{2} \mathrm{O}_{2}$ ( $1.5 \mathrm{~mm}$ ), however, caused a marked increase in DCF fluorescence in these cells, confirming successful dye loading (data not shown).

Effects of MCS-enhanced $\mathrm{H}_{2} \mathrm{O}_{2}$ are mediated by $\mathrm{K}_{\text {ATP }}$ channels Voltage-clamp measurements indicated that MCS induced an outward current $(107 \pm 4 \mathrm{pA} ; n=4)$, consistent with $\mathrm{K}^{+}$channel opening, which ceased after MCS washout (Fig. 6a). The suppression of spontaneous activity in responders seen in current-clamp mode was reversed by glibenclamide (either $100 \mathrm{nM}$ or $3 \mu \mathrm{M}$ ) during continued exposure to MCS (Fig. $6 b$ ), with restoration of membrane potential, input resistance, and sag (Fig. $6 c)(n=10)$. Glibenclamide at $100 \mathrm{nM}$ was as effective as $3 \mu \mathrm{M}$ in restoring membrane properties, although the recovery rate was slower than that seen with $3 \mu \mathrm{M}$. These data demonstrate that elevated levels 
of endogenous $\mathrm{H}_{2} \mathrm{O}_{2}$ can cause hyperpolarization in a large population of DA neurons via $\mathrm{K}_{\mathrm{ATP}}$ channels.

\section{Effect of exogenous $\mathrm{H}_{2} \mathrm{O}_{2}$ on DA neurons}

To confirm the specific involvement of $\mathrm{H}_{2} \mathrm{O}_{2}$, we tested whether the effects of MCS could be mimicked by exogenously applied $\mathrm{H}_{2} \mathrm{O}_{2}$, using the minimum concentration of $\mathrm{H}_{2} \mathrm{O}_{2}(1.5 \mathrm{~mm})$ found previously to inhibit DA release in striatal slices (Chen et al., 2001). We again found that one population of DA cells was physiologically responsive to $\mathrm{H}_{2} \mathrm{O}_{2}$ (10 min application), whereas a second population was not. In responders (53\%; $n=15$ of 28 ), current-clamp recording showed that exogenous $\mathrm{H}_{2} \mathrm{O}_{2}$ induced an average membrane hyperpolarization of $12 \pm 2.7 \mathrm{mV}$ $\left(n=15 ; p<0.001\right.$ control vs $\left.\mathrm{H}_{2} \mathrm{O}_{2}\right)$, with a $39 \%$ decrease in membrane resistance (from $193 \pm 20$ to $118 \pm 15 \mathrm{M} \Omega ; n=15$; $p<0.001)$ accompanied by loss of sag. These changes were accompanied by suppression of spontaneous activity (Fig. 7a). All of these effects were reversible with $\mathrm{H}_{2} \mathrm{O}_{2}$ washout. In nonresponders (47\%; $n=13$ of 28), $\mathrm{H}_{2} \mathrm{O}_{2}$ had no effect on any physiological parameter examined (Fig. $7 b$ ). Thus, the relative proportions of responders and nonresponders to exogenously applied $\mathrm{H}_{2} \mathrm{O}_{2}$ were the same as with MCS. Moreover, in a separate study, we found that DA neurons that hyperpolarized with MCS also hyperpolarized with exogenous $\mathrm{H}_{2} \mathrm{O}_{2}$ ( $n=3$ of 5$)$, whereas nonresponders did not respond to either MCS or $\mathrm{H}_{2} \mathrm{O}_{2}(n=2$ of 5$)$. Either glibenclamide ( $3 \mu \mathrm{M} ; n=7$ ) or another sulfonylurea $\mathrm{K}_{\mathrm{ATP}}$ channel blocker, tolbutamide (200 $\mu \mathrm{M} ; n=2)$, completely reversed the suppression of spontaneous activity in responders in the presence of exogenous $\mathrm{H}_{2} \mathrm{O}_{2}$ (Fig. $7 c$ ), confirming $\mathrm{K}_{\text {ATP }}$ channel involvement. Recovery of spontaneous activity and membrane resting potential was never seen during prolonged $\mathrm{H}_{2} \mathrm{O}_{2}$ application alone.

Representative responders and nonresponders filled with $\mathrm{Lu}-$ cifer yellow were also TH positive, confirming that both populations were DA neurons. Both cell types were found throughout the SNc, with no obvious pattern of anatomical localization. The physiological characteristics of responders $(n=35)$ and nonresponders $(n=31)$ to either exogenous or endogenous (exposure to $1 \mathrm{~mm} \mathrm{MCS}) \mathrm{H}_{2} \mathrm{O}_{2}$ were also indistinguishable for all parameters tested ( $p>0.05$ for responders vs nonresponders). These parameters included spontaneous firing rate (responders, $3.0 \pm$ $0.3 \mathrm{~Hz}$; nonresponders, $3.0 \pm 0.3 \mathrm{~Hz}$ ), input resistance (responders, $194 \pm 18 \mathrm{M} \Omega$; nonresponders, $189 \pm 17 \mathrm{M} \Omega$ ), sag amplitude seen with $-0.2 \mathrm{nA}$ injection (responders: $27.3 \pm 0.9 \mathrm{mV}$; range, 19.8-36.9 mV; nonresponders: $26.9 \pm 0.8 \mathrm{mV}$; range, 20.4-37.9), and delay in rebound firing after hyperpolarizing current injection (responders: $478 \pm 45 \mathrm{~ms}$; range, $234-1299 \mathrm{~ms}$; nonresponders: $525 \pm 50 \mathrm{~ms}$; range, $235-1156 \mathrm{~ms}$ ).
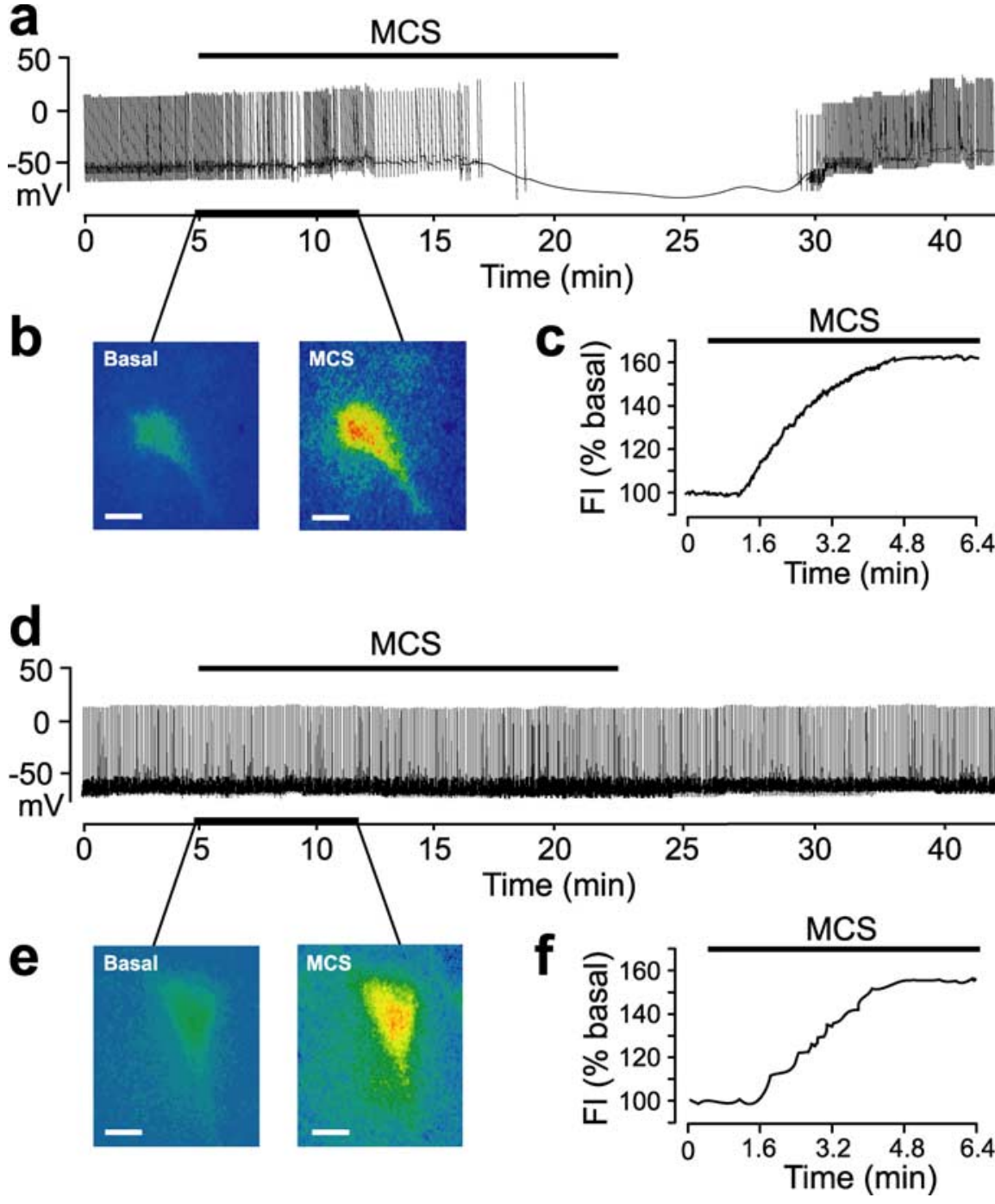

Figure 4. Effects of GSH peroxidase inhibition on membrane properties and $\mathrm{H}_{2} \mathrm{O}_{2} \cdot \boldsymbol{a}$, Inhibition of GSH peroxidase by MCS ( 1 $\mathrm{mm}$ ) caused hyperpolarization and cessation of spontaneous activity in one population of DA neurons (responders; $n=20$ of 38) , Simulaneously recorded DCF fluorescence in the responder in $\boldsymbol{a}$ before (Basal) and during MCS exposure. $c$, Time course of $\mathrm{H}_{2} \mathrm{O}$ elevation [fluorescence intensity (FI)] in this cell. $\boldsymbol{d}$, MCS did not affect spontaneous activity in a second population of DA neurons (nonresponders; $n=18$ of 38). $\boldsymbol{e}$, Simultaneously recorded DCF fluorescence images before and during MCS in the nonresponder in $\boldsymbol{d}$. $\boldsymbol{f}$, Time course of $\mathrm{H}_{2} \mathrm{O}_{2}$ elevation in this cell. Scale bars, $20 \mu \mathrm{m}$.

\section{Responsiveness to $\mathrm{H}_{2} \mathrm{O}_{2}$ depends on SUR subunit of} $\mathrm{K}_{\mathrm{ATP}}$ channels

Previous studies indicate that two major populations of DA neurons in the $\mathrm{SNc}$ can be distinguished by the sensitivity of $\mathrm{K}_{\mathrm{ATP}}$ channel opening to metabolic stress, with greater sensitivity of SUR1 - versus SUR2-expressing cells (Liss et al., 1999). We therefore examined the role of SUR 1 and SUR $2 \mathrm{~K}_{\mathrm{ATP}}$ channel isoforms in conveying sensitivity to elevated $\mathrm{H}_{2} \mathrm{O}_{2}$. We addressed this pharmacologically using diazoxide $(60 \mu \mathrm{M})$, a SUR1-selective opener, and cromakalim $(60 \mu \mathrm{M})$, a SUR2-selective opener. Our experimental design took into account a previous observation that diazoxide can act at SUR2B-containing as well as SUR1containing $\mathrm{K}_{\mathrm{ATP}}$ channels in muscle cells (Isomoto et al., 1996). We ascertained whether a given cell was a responder or nonresponder during a 10 min exposure to exogenous $\mathrm{H}_{2} \mathrm{O}_{2}$, followed by $\mathrm{H}_{2} \mathrm{O}_{2}$ washout, then sequentially applied diazoxide and cromakalim to the same cell. For responders, cromakalim was applied first, followed by diazoxide, with the opposite protocol for nonresponders. Cromakalim had no effect on most responders 


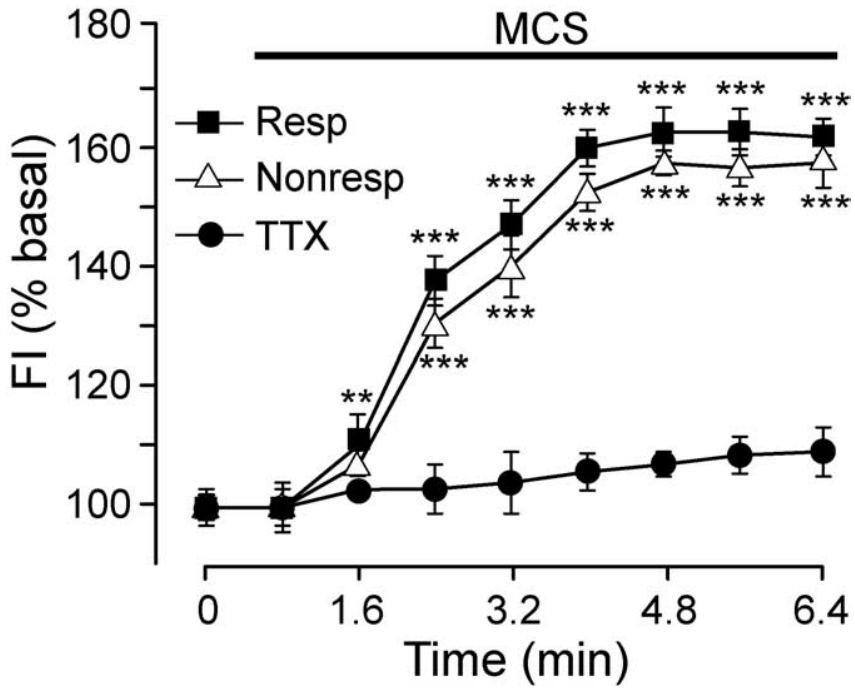

Figure 5. Activity-dependent $\mathrm{H}_{2} \mathrm{O}_{2}$ generation in DA neurons. The average time course and amplitude of MCS-induced increases in intracellular $\mathrm{H}_{2} \mathrm{O}_{2}$ in responders (Resp; $n=7$ ) and nonresponders (Nonresp; $n=7$ ) is shown. Fl, DCF fluorescence intensity. Intracellular levels of $\mathrm{H}_{2} \mathrm{O}_{2}$ did not change when MCS was applied in the presence of TTX (1 $\left.\mu \mathrm{M} ; n=3\right)$, indicating that MCS-induced increases in $\mathrm{H}_{2} \mathrm{O}_{2}$ require action potentials. Data are means \pm SEM. ${ }^{* *} p<$ 0.01 and $^{* * *} p<0.001$ versus basal fluorescence; neither time course nor amplitude differed significantly between responders and nonresponders.

( $n=5$ of 6 ), indicating a lack of involvement of SUR2 subunits; in contrast, diazoxide caused hyperpolarization and cessation of spontaneous activity in all of these cells ( $n=6$ of 6) (Fig. $8 a$ ). Nonresponders showed the opposite response pattern, with no

a
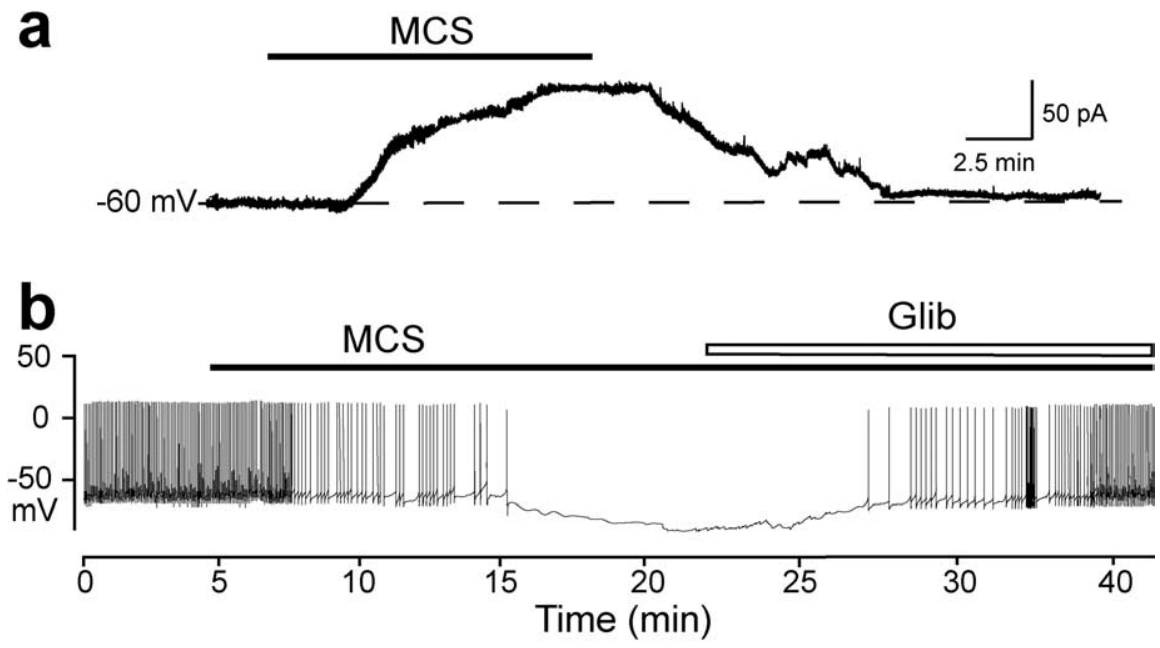

C

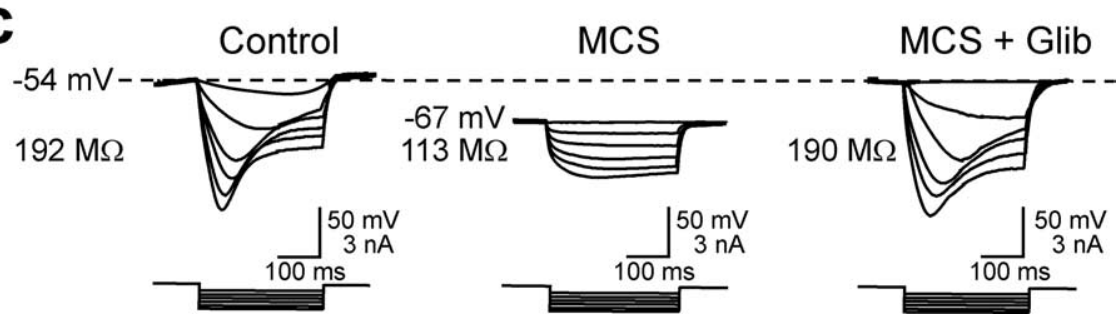

Figure 6. Endogenous $\mathrm{H}_{2} \mathrm{O}_{2}$ activates $\mathrm{K}_{\text {ATP }}$ channels. $\boldsymbol{a}$, Representative voltage-clamp record from a DA neuron during MCS application showing activation of an outward current. $\boldsymbol{b}$, Glibenclamide (Glib; $3 \mu \mathrm{m}$ ) reversed the MCS-induced membrane hyperpolarization and loss of spontaneous firing in the presence of MCS. $c$, Voltage responses to hyperpolarizing current recorded in this cell under control conditions, in MCS, and in MCS plus Glib. response to diazoxide ( $n=5$ of 6 ) but hyperpolarization with cromakalim ( $n=6$ of 6 ) (Fig. $8 b$ ). These data suggest that diazoxide at the concentration tested has no effect on SUR2Bcontaining $\mathrm{K}_{\mathrm{ATP}}$ channels in DA neurons. Although one cell in each group showed membrane hyperpolarization in response to both diazoxide and cromakalim, this presumably reflected dual expression of both SUR isoforms (Liss et al., 1999). Membrane hyperpolarization induced by diazoxide or cromakalim was also accompanied by a decrease in input resistance and loss of sag.

One other caveat in the use of diazoxide is that it can cause an increase in reactive oxygen species (ROS) generation, detected by DCF fluorescence (Forbes et al., 2001). To address this concern, we examined the effect of $60 \mu \mathrm{M}$ diazoxide on DCF fluorescence in DA neurons. We found that diazoxide caused an increase of $18 \pm 1 \%(p<0.05$ vs basal), whether the cell hyperpolarized with diazoxide ( $n=5$ of 7$)$ or not $(n=2$ of 7$)$. Our studies of graded $\mathrm{H}_{2} \mathrm{O}_{2}$ generation with $\mathrm{GSH}$ peroxidase inhibition, however, suggest that the $\mathrm{H}_{2} \mathrm{O}_{2}$ levels indicated by an $18 \%$ increase in DCF fluorescence (Fig. 3) would be insufficient to alter membrane properties of DA neurons. Thus, the hyperpolarization seen with diazoxide appears to be from its conventional action as a $\mathrm{K}_{\mathrm{ATP}}$ channel opener.

\section{Inhibition of catalase}

In $\mathrm{SNc}$, the activity of endogenous catalase is much higher than that of GSH peroxidase (Hung and Lee, 1998). We therefore examined the effect of catalase inhibition on DA cell physiology using ATZ (1 mM) (Desagher et al., 1996). Catalase inhibition by ATZ caused membrane hyperpolarization and loss of spontaneous activity in all neurons tested $(n=12)$ (Fig. $9 a)$. The effect reversed after ATZ washout (Fig. 9a). Intracellular $\mathrm{H}_{2} \mathrm{O}_{2}$ increased sharply during ATZ application (Fig. 9b,c). In comparisons of the time course and amplitude of changes in DCF fluorescence with MCS versus ATZ, we found that the initial increase in DCF fluorescence with ATZ was significantly greater than with MCS, with a $t_{50}$ (time of $50 \%$ maximal response) of $1.4 \pm 0.1 \min (n=5)$ for ATZ versus $2.1 \pm$ $0.2 \min (n=5 ; p<0.01)$ for MCS responders (Fig. 9d,e) and $2.3 \pm 0.2 \mathrm{~min}$ $(n=5 ; p<0.01)$ for MCS nonresponders. Moreover, DCF fluorescence with ATZ was significantly greater at all time points than that seen in MCS nonresponders (Fig. 9d,e). The effects of ATZ could be reversed by glibenclamide, confirming $\mathrm{K}_{\mathrm{ATP}}$ channel involvement $(n=4)$ (Fig. 9f), although $10 \mu \mathrm{M}$ rather than $3 \mu \mathrm{M}$ glibenclamide was required. These data suggest that above a certain level, $\mathrm{H}_{2} \mathrm{O}_{2}$ can lead to $\mathrm{K}_{\mathrm{ATP}}$ channel activation in all DA neurons.

\section{Discussion}

Here, we introduce $\mathrm{H}_{2} \mathrm{O}_{2}$ as a key signaling element [or "cytosolic factor" (Ashcroft and Gribble, 1998)] that, along with ATP, links metabolism and cell activity via $\mathrm{K}_{\mathrm{ATP}}$ channels. The data demonstrate tonic regulation of DA cell firing rate by $\mathrm{H}_{2} \mathrm{O}_{2}$ sensitive $\mathrm{K}_{\mathrm{ATP}}$ channels, as well as addi- 
tional patterns of $\mathrm{K}_{\mathrm{ATP}}$ channel regulation when $\mathrm{H}_{2} \mathrm{O}_{2}$ rises above basal levels. Although the moderate $\mathrm{H}_{2} \mathrm{O}_{2}$ elevation that accompanied partial GSH peroxidase inhibition by $0.1-0.3 \mathrm{~mm}$ MCS did not alter the firing rate or membrane properties in any recorded cell, the higher elevation seen with GSH peroxidase inhibition by $1 \mathrm{~mm}$ MCS or application of exogenous $\mathrm{H}_{2} \mathrm{O}_{2}$ caused $\mathrm{K}_{\text {ATP }}$ channel-dependent hyperpolarization in $\sim 50 \%$ of DA neurons. With the more rapid $\mathrm{H}_{2} \mathrm{O}_{2}$ elevation caused by catalase inhibition, all DA neurons exhibited $\mathrm{K}_{\mathrm{ATP}}$ channel-dependent hyperpolarization. Thus, $\mathrm{H}_{2} \mathrm{O}_{2}$ acts in a graded manner to regulate DA cell excitability.

Tonic regulation of DA neuron activity by $\mathrm{H}_{2} \mathrm{O}_{2}$-sensitive $\mathrm{K}_{\mathrm{ATP}}$ channels Most endogenously produced ROS, including $\mathrm{H}_{2} \mathrm{O}_{2}$, are derived from mitochondrial respiration (Dugan et al., 1995; Liu et al., 2002), with 1-2\% of consumed oxygen converted to superoxide radical then to $\mathrm{H}_{2} \mathrm{O}_{2}$ (Boveris and Chance, 1973; Cohen, 1994). Notably, $\mathrm{H}_{2} \mathrm{O}_{2}$ is not a free radical (all of its electrons are paired) and does not readily cause oxidative damage (Cohen, 1994), making it an ideal ROS to act as a signaling agent.

In the present studies, basal $\mathrm{H}_{2} \mathrm{O}_{2}$ levels were detected in all recorded DA neurons during normal pacemaker activity. A resting $\mathrm{K}_{\mathrm{ATP}}$ channel tone was also seen in all cells, indicated by a significant increase in the spontaneous firing rate in the presence of glibenclamide with both conventional whole-cell and perforated-patch recording. Moreover, a similar increase in the spontaneous firing frequency accompanied depletion of intracellular $\mathrm{H}_{2} \mathrm{O}_{2}$ when catalase was included in the whole-cell backfill solution. The catalase-induced increase in the firing rate was prevented by glibenclamide, confirming that tonically generated $\mathrm{H}_{2} \mathrm{O}_{2}$ regulates DA neuron excitability via $\mathrm{K}_{\mathrm{ATP}}$ channels. $\mathrm{K}_{\mathrm{ATP}}$ channel modulation by $\mathrm{H}_{2} \mathrm{O}_{2}$ may not be unique to DA neurons, because a resting $\mathrm{K}_{\mathrm{ATP}}$ channel tone has also been demonstrated in striatal cholinergic interneurons using perforated-patch recording (Lee et al., 1998).

Importantly, the backfill solution in the present studies contained $3 \mathrm{~mm}$ ATP, at which concentration $\mathrm{K}_{\mathrm{ATP}}$ channels should be closed (Häusser et al., 1991; Roeper and Ashcroft, 1995; Stanford and Lacey, 1995; Inagaki et al., 1996). Thus, it is unlikely that the resting $\mathrm{K}_{\mathrm{ATP}}$ channel tone in DA neurons was caused by low ATP. Rather, our data suggest that the active regulator is $\mathrm{H}_{2} \mathrm{O}_{2}$. Indeed, previous studies using inside-out mem-
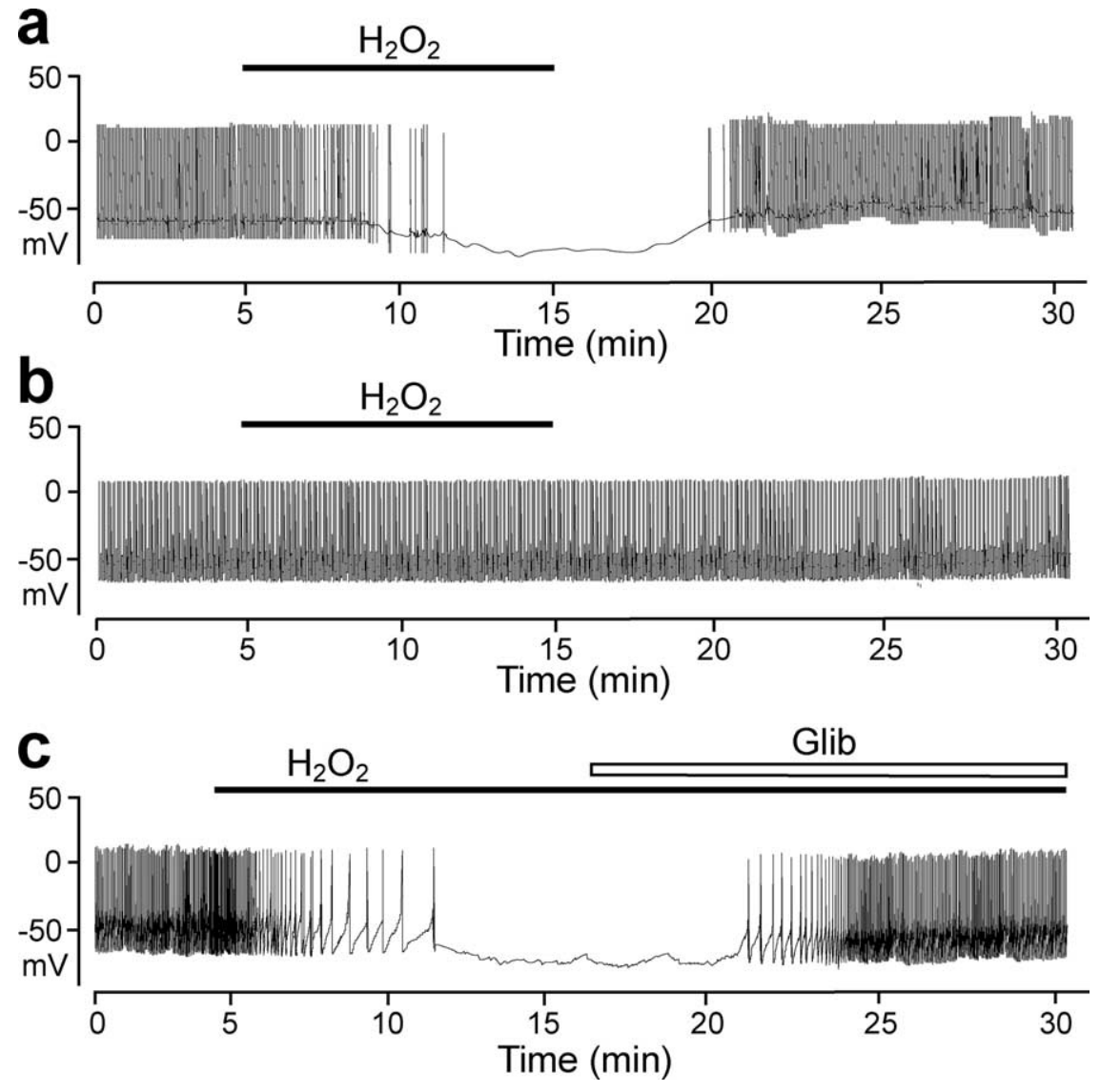

Figure 7. Effect of exogenous $\mathrm{H}_{2} \mathrm{O}_{2}$ on physiological properties of DA neurons. $a$, Exogenous $\mathrm{H}_{2} \mathrm{O}_{2}(1.5 \mathrm{~mm})$ applied for $10 \mathrm{~min}$ caused a reversible membrane hyperpolarization and loss of spontaneous firing activity in one population of identified DA neurons (responders; $n=15$ of 28 ) but not in a second population of DA cells $(\boldsymbol{b} ;$ nonresponders; $n=13$ of 28 ). $\boldsymbol{c}$, Current-clamp recording from a responder during application of exogenous $\mathrm{H}_{2} \mathrm{O}_{2}$; glibenclamide (Glib; $3 \mu \mathrm{M}$ ) reversed the $\mathrm{H}_{2} \mathrm{O}_{2}$-induced membrane hyperpolarization and restored spontaneous activity in the continuous presence of $\mathrm{H}_{2} \mathrm{O}_{2}(n=7)$.

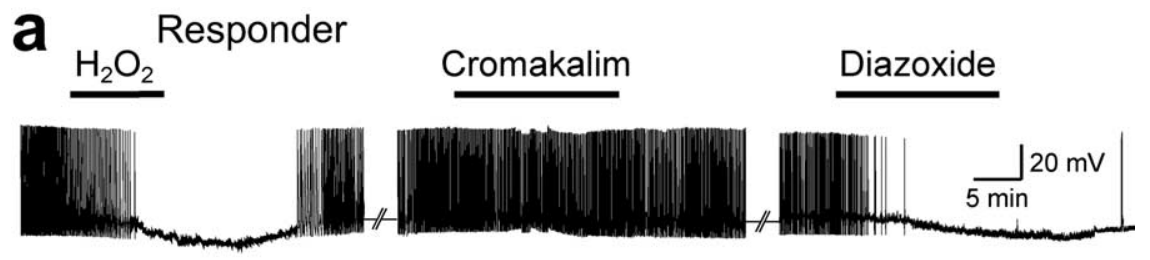

\section{b Nonresponder}

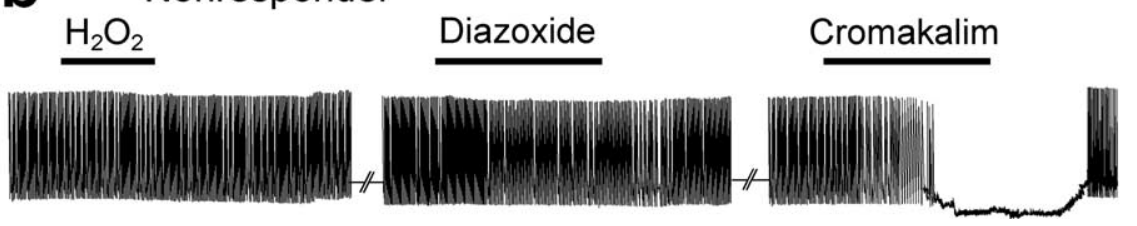

Figure 8. Effect of SUR1- and SUR2-selective $\mathrm{K}_{\mathrm{ATP}}$ channel openers on $\mathrm{H}_{2} \mathrm{O}_{2}$ responders and nonresponders. $\boldsymbol{a}$, Representative continuous current-clamp recording in a responder: $\mathrm{H}_{2} \mathrm{O}_{2}(1.5 \mathrm{~mm})$ caused membrane hyperpolarization and inhibition of spontaneous firing activity in this DA neuron; cromakalim ( $60 \mu \mathrm{m}$; $20 \mathrm{~min}$ ) had no effect, whereas subsequently applied diazoxide (60 $\mu \mathrm{m} ; 20 \mathrm{~min}$ ) caused hyperpolarization and loss of spontaneous activity. $\boldsymbol{b}$, Representative current-clamp recording in a nonresponder: $\mathrm{H}_{2} \mathrm{O}_{2}$ (1.5 mm) applied for 10 min did not alter membrane properties; diazoxide had no effect, whereas subsequently applied cromakalim caused membrane hyperpolarization and loss of spontaneous activity.

brane patches from cardiac cells have shown a direct, concentration-dependent effect of $\mathrm{H}_{2} \mathrm{O}_{2}$ on $\mathrm{K}_{\text {ATP }}$ channel opening by decreasing channel sensitivity to ATP (Ichinari et al., 1996; Tokube et al., 1998). The mechanism underlying this effect is not 
a

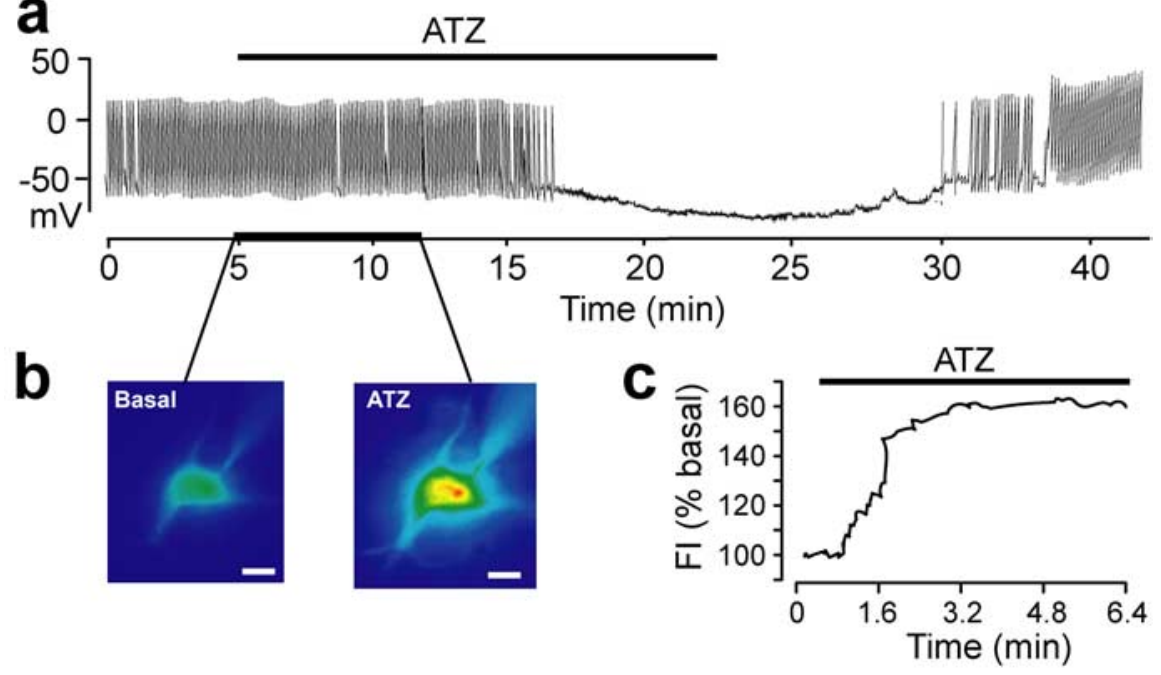

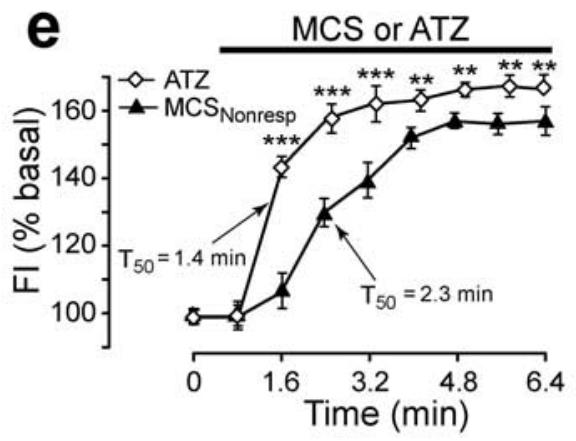

f

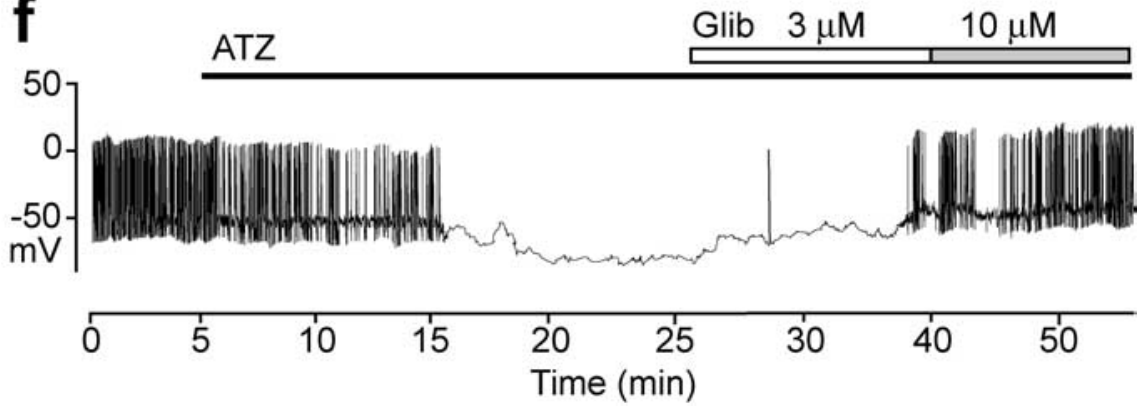

Figure 9. Effects of catalase inhibition on membrane properties and $\mathrm{H}_{2} \mathrm{O}_{2}$. $\boldsymbol{a}$, Current-clamp record showing a reversible membrane hyperpolarization and loss of spontaneous firing in a DA neuron by catalase inhibition with ATZ (1 mM); all DA neurons responded to ATZ $(n=12)$. $\boldsymbol{b}$, Simultaneously recorded DCF fluorescence in this cell before (Basal) and during ATZ exposure confirmed $\mathrm{H}_{2} \mathrm{O}_{2}$ elevation. Scale bar, $20 \mu \mathrm{m}$. c, Time course of $\mathrm{H}_{2} \mathrm{O}_{2}$ increase. Fl, Fluorescence intensity. $\boldsymbol{d}$, e, Average time course and amplitude of $\mathrm{H}_{2} \mathrm{O}_{2}$ increases induced by ATZ versus those in MCS responders ( $\boldsymbol{d}$; MCS $\mathrm{Resp}_{\text {p }}$ ) and MCS nonresponders (e; $\mathrm{MCS}_{\text {Nonresp }}$ ). Data are means \pm SEM. ${ }^{* *} p<0.01$ and ${ }^{* * *} p<0.001$ versus MCS. $\boldsymbol{f}$, Glibenclamide (Glib; $10 \mu \mathrm{m}$ ) reversed ATZ-induced membrane hyperpolarization and loss of cell firing in the continued presence of ATZ $(n=4)$.

known; however, it cannot involve complete oxidation of redoxsensitive sites in $\mathrm{K}_{\mathrm{ATP}}$ channels, because strong oxidants cause $\mathrm{K}_{\mathrm{ATP}}$ channel closure (Coetzee et al., 1995).

\section{Functional consequences of endogenous $\mathrm{H}_{2} \mathrm{O}_{2}$ elevation} We also found that intracellular $\mathrm{H}_{2} \mathrm{O}_{2}$ levels increased during depolarization-induced increases in DA cell activity (Fig. 1a), which is the first demonstration of activity-dependent $\mathrm{H}_{2} \mathrm{O}_{2}$ generation in single cells in brain tissue. The dependence of $\mathrm{H}_{2} \mathrm{O}_{2}$ generation on cell activity was further demonstrated by the TTX sensitivity of the increase in DCF fluorescence seen during GSH peroxidase inhibition by MCS. The amplification of activitydependent $\mathrm{H}_{2} \mathrm{O}_{2}$ levels by MCS provided a means to examine the effect of elevated $\mathrm{H}_{2} \mathrm{O}_{2}$ on DA cell physiology. A progressive increase in DCF fluorescence was seen with increasing GSH peroxidase inhibition. Moderate increases in $\mathrm{H}_{2} \mathrm{O}_{2}$ (e.g., those indicated by a $25 \%$ increase in fluorescence intensity) were not accompanied by changes in membrane properties. However, the increase in endogenous $\mathrm{H}_{2} \mathrm{O}_{2}$ seen with $1 \mathrm{~mm}$ MCS was sufficient to cause profound hyperpolarization and loss of spontaneous activity in $50 \%$ of DA neurons; a second population was not responsive, despite equivalent increases in intracellular $\mathrm{H}_{2} \mathrm{O}_{2}$. A similar distribution of responders and nonresponders was seen during application of exogenous $\mathrm{H}_{2} \mathrm{O}_{2}$. Exogenous $\mathrm{H}_{2} \mathrm{O}_{2}$ has been shown in previous studies to activate $\mathrm{K}^{+}$channels in a variety of cell types, including hippocampal CA1 neurons, cardiac myocytes, and pancreatic $\beta$-cells (Seutin et al., 1995; Ichinari et al., 1996; Tokube et al., 1998; Krippeit-Drews et al., 1999). Here, reversal of $\mathrm{H}_{2} \mathrm{O}_{2}$-dependent hyperpolarization by glibenclamide confirmed the involvement of $\mathrm{K}_{\mathrm{ATP}}$ channels in DA neurons.

In contrast to the differential responses seen with GSH peroxidase, all DA cells responded with hyperpolarization and loss of spontaneous activity when catalase was inhibited by ATZ. Moreover, DCF imaging demonstrated a faster rate of $\mathrm{H}_{2} \mathrm{O}_{2}$ amplification in DA neurons with ATZ versus MCS. The enhanced effects of ATZ are consistent with the dominant role of catalase in managing neuronal $\mathrm{H}_{2} \mathrm{O}_{2}$ in the SNc: not only is catalase activity 20 -fold higher than GSH peroxidase activity (Hung and Lee, 1998), GSH peroxidase is primarily glial, with weak expression in DA neurons (Damier et al., 1993; Trépanier et al., 1996). Whether regulation of $\mathrm{K}_{\mathrm{ATP}}$ channels by elevated $\mathrm{H}_{2} \mathrm{O}_{2}$ is direct or indirect in DA neurons remains to be elucidated. In isolated pancreatic $\beta$-cells, activation of $\mathrm{K}_{\mathrm{ATP}}$ channels by exogenous $\mathrm{H}_{2} \mathrm{O}_{2}$ was accompanied by a fall in ATP, implying an indirect action of $\mathrm{H}_{2} \mathrm{O}_{2}$; however, the observed membrane hyperpolarization was irreversible (Krippeit-Drews et al., 1999). In contrast, the $\mathrm{K}_{\mathrm{ATP}}$ channel-dependent hyperpolarization of DA neurons seen with all agents, including ATZ, reversed after washout, suggesting that mechanisms required to maintain cell viability, including ATP generation and ion homeostasis, were not irreversibly damaged.

Diversity of DA neuron responsiveness to $\mathrm{H}_{2} \mathrm{O}_{2}$

Diversity of DA cell characteristics is well known, although often disregarded. Dorsal- and ventral-tier DA cells in the SNc can be distinguished by differential expression of calbindin, with higher levels in dorsal-tier versus ventral-tier neurons, and by differences in their striatal projection targets (Gerfen et al., 1987; Han- 
ley and Bolam, 1997; Prensa and Parent, 2001; Neuhoff et al., 2002). Additionally, subtle differences in physiological characteristics, including sag amplitude and delay in rebound firing activity, have been detected in DA cell populations identified by differential calbindin expression (Neuhoff et al., 2002). Additionally, Liss et al. (1999) identified two populations of DA cells in mouse SNc that were defined by differential sensitivity to mitochondrial inhibition, with a greater sensitivity of cells expressing SUR1- versus SUR2-based $\mathrm{K}_{\mathrm{ATP}}$ channels.

In the present studies, we found no differences in the physiological characteristics of responders and nonresponders, indicating that these populations include both calbindin-positive and -negative cells. Rather, the populations defined by differential sensitivity to $\mathrm{H}_{2} \mathrm{O}_{2}$ seem to reflect the distribution of DA neurons expressing SUR1- and SUR2-based $\mathrm{K}_{\mathrm{ATP}}$ channels (Liss et al. 1999). Indeed, our pharmacological studies with diazoxide and cromakalim suggest that the sensitivity of responders to amplified $\mathrm{H}_{2} \mathrm{O}_{2}$ is conveyed by SUR1-based $\mathrm{K}_{\text {ATP }}$ channels (Fig. 7). Although nonspecific effects of diazoxide have been reported, including ROS generation and mitochondrial dysfunction (Forbes et al., 2001), the $\mathrm{H}_{2} \mathrm{O}_{2}$ elevation seen in the present studies was below that required to activate $\mathrm{K}_{\mathrm{ATP}}$ channels.

Hyperpolarization of all DA cells with ATZ suggests that the $\mathrm{H}_{2} \mathrm{O}_{2}$ levels achieved were sufficient to recruit SUR2-based as well as SUR1-based $\mathrm{K}_{\mathrm{ATP}}$ channels, because SUR2-expressing as well as SUR1-expressing neurons must be affected. The higher concentration of glibenclamide ( $10 \mathrm{vs} 3 \mu \mathrm{M})$ required to reverse ATZ-induced hyperpolarization would also be consistent with SUR2-based channel recruitment, because these are less sensitive to glibenclamide than are SUR1-based channels (Inagaki et al., 1996), with the caveat that $10 \mu \mathrm{M}$ glibenclamide can have nonspecific effects on other $\mathrm{K}^{+}$channels (Crepel et al., 1993).

\section{Summary and conclusions}

We show here that DA neuron excitability is regulated by $\mathrm{H}_{2} \mathrm{O}_{2}$ via $\mathrm{K}_{\mathrm{ATP}}$ channels. Regulation of spontaneous activity in all DA neurons suggests that this tonic control is independent of SUR subunit composition, perhaps implicating a modulatory site on pore-forming subunits. In contrast, differential sensitivity of DA neurons to elevated $\mathrm{H}_{2} \mathrm{O}_{2}$ is defined by SUR subunit composition.

Given the dependence of both axon terminal and somatodendritic DA release on DA cell firing rate (Gonon and Buda, 1985; Rice et al., 1997), $\mathrm{H}_{2} \mathrm{O}_{2}$-dependent regulation of DA cell activity would influence DA release throughout the nigrostriatal pathway. Indeed, GSH peroxidase inhibition by MCS (1 mM) causes suppression of somatodendritic DA release in the $\mathrm{SNc}$ (Chen et al., 2002). These data have pathophysiological implications because GSH content and GSH peroxidase activity in the SNc fall in Parkinson's disease (Damier et al., 1993; Olanow and Tatton, 1999). The involvement of $K_{\text {ATP }}$ channels in the regulation of DA release in vivo and the potential importance of this in movement control has been suggested by behavioral studies showing that unilateral nigral injection of tolbutamide induces rotation behavior in rats given systemic amphetamine (Levesque and Greenfield, 1991). Additionally, SUR1-containing $\mathrm{K}_{\mathrm{ATP}}$ channels are required for inhibition of DA release by endogenous $\mathrm{H}_{2} \mathrm{O}_{2}$ in the striatum (Avshalumov and Rice, 2003). Although diazoxide and cromakalim each decrease evoked DA release in the striatum by $\sim 40 \%$, only SUR1selective diazoxide prevents additional suppression by endogenous $\mathrm{H}_{2} \mathrm{O}_{2}$. These data suggest that the 50:50 distribution of responders and nonresponders in the $\mathrm{SNc}$ is reflected in the pattern of functional $\mathrm{K}_{\mathrm{ATP}}$ channel expression in striatal DA axons.
The present findings extend a growing body of evidence indicating that ROS, including $\mathrm{H}_{2} \mathrm{O}_{2}$, are important signaling molecules (Sundaresan et al., 1995; Nishida et al., 2000; Kamsler and Segal, 2004). Given that exogenous $\mathrm{H}_{2} \mathrm{O}_{2}$ can activate $\mathrm{K}^{+}$ channels in a variety of cell types and that SUR1-based $\mathrm{K}_{\mathrm{ATP}}$ channels are widely expressed by neurons in the CNS (ScuveeMoreau et al., 1997; Lee et al., 1998; Liss et al., 1999), it is unlikely that regulation of cell activity by $\mathrm{H}_{2} \mathrm{O}_{2}$ and $\mathrm{K}_{\text {ATP }}$ channels is unique to DA neurons in the SNc. Thus, demonstrated sensitivity of $\mathrm{K}_{\text {ATP }}$ channels to $\mathrm{H}_{2} \mathrm{O}_{2}$ in intact neurons reveals a mechanism that could modulate physiological functions from excitability and transmitter release to differential cell responses to ischemia or metabolic stress.

\section{References}

Albin RL, Young AB, Penney JB (1989) The functional anatomy of basal ganglia disorders. Trends Neurosci 12:366-375.

Amoroso S, Schmid-Antomarchi H, Fosset M, Lazdunski M (1990) Glucose, sulfonylureas, and neurotransmitter release: role of ATP-sensitive $\mathrm{K}^{+}$channels. Science 247:852-854.

Ashcroft FM, Gribble FM (1998) Correlating structure and function in ATP-sensitive $\mathrm{K}^{+}$channels. Trends Neurosci 21:288-294.

Ashcroft SJ, Ashcroft FM (1990) Properties and functions of ATP-sensitive K-channels. Cell Signal 2:197-214.

Avshalumov MV, Rice ME (2003) Activation of ATP-sensitive $\mathrm{K}^{+}\left(\mathrm{K}_{\mathrm{ATP}}\right)$ channels by $\mathrm{H}_{2} \mathrm{O}_{2}$ underlies glutamate-dependent inhibition of striatal dopamine release. Proc Natl Acad Sci USA 100:11729-11734.

Avshalumov MV, Chen BT, Marshall SP, Peña DM, Rice ME (2003) Glutamate-dependent inhibition of dopamine release in striatum is mediated by a new diffusible messenger, $\mathrm{H}_{2} \mathrm{O}_{2}$. J Neurosci 23:2744-2750.

Babenko AP, Aguilar-Bryan L, Bryan J (1998) A view of SUR/K $\mathrm{IR} 6 . \mathrm{X}, \mathrm{K}_{\mathrm{ATP}}$ channels. Annu Rev Physiol 60:667-687.

Boveris A, Chance B (1973) The mitochondrial generation of hydrogen peroxide. General properties and effect of hyperbaric oxygen. Biochem J 134:707-716.

Chen BT, Avshalumov MV, Rice ME (2001) $\mathrm{H}_{2} \mathrm{O}_{2}$ is a novel, endogenous modulator of synaptic dopamine release. J Neurophysiol 85:2468-2476.

Chen BT, Avshalumov MV, Rice ME (2002) Modulation of somatodendritic dopamine release by endogenous $\mathrm{H}_{2} \mathrm{O}_{2}$ : susceptibility in substantia nigra but resistance in VTA. J Neurophysiol 87:1155-1158.

Coetzee WA, Nakamura TY, Faivre JF (1995) Effects of thiol-modifying agents on $\mathrm{K}_{\mathrm{ATP}}$ channels in guinea pig ventricular cells. Am J Physiol 269:H1625-H1633.

Cohen G (1994) Enzymatic/nonenzymatic sources of oxyradicals and regulation of antioxidant defenses. Ann NY Acad Sci 738:8-14.

Cook DL, Hales CN (1984) Intracellular ATP directly blocks $\mathrm{K}^{+}$channels in pancreatic $\beta$-cells. Nature 311:271-273

Crepel V, Krnjevic K, Ben-Ari Y (1993) Sulphonylureas reduce the slowly inactivating D-type outward current in rat hippocampal neurons. J Physiol (Lond) 466:39-54.

Dahlstrom A, Fuxe K (1964) Localization of monoamines in the lower brain stem. Experientia 20:398-399.

Damier P, Hirsch EC, Zhang P, Agid Y, Javoy-Agid F (1993) Glutathione peroxidase, glial cells and Parkinson's disease. Neuroscience 52:1-6.

Desagher S, Glowinski J, Premont J (1996) Astrocytes protect neurons from hydrogen peroxide toxicity. J Neurosci 16:2553-2562.

Dringen R, Kussmaul L, Hamprecht B (1998) Rapid clearance of tertiary butyl hydroperoxide by cultured astroglial cells via oxidation of glutathione. Glia 23:139-145.

Dugan LL, Sensi SL, Canzoniero LM, Handran SD, Rothman SM, Lin TS, Goldberg MP, Choi DW (1995) Mitochondrial production of reactive oxygen species in cortical neurons following exposure to $N$-methyl-Daspartate. J Neurosci 15:6377-6388.

Forbes RA, Steenbergen C, Murphy E (2001) Diazoxide-induced cardioprotection requires signaling through a redox-sensitive mechanism. Circ Res 88:802-809.

Gerfen CR, Baimbridge KG, Thibault J (1987) The neostriatal mosaic: III. Biochemical and developmental dissociation of patch-matrix mesostriatal systems. J Neurosci 7:3935-3944.

Gonon FG, Buda M (1985) Regulation of dopamine release by impulse flow 
and by autoreceptors as studied by in vivo voltammetry in the rat striatum. Neuroscience 14:765-774.

Grace AA, Onn S-P (1989) Morphology and electrophysiological properties of immunocytochemically identified rat dopamine neurons recorded in vitro. J Neurosci 9:3463-3481.

Guatteo E, Federici M, Siniscalchi A, Knopfel T, Mercuri NB, Bernardi G (1998) Whole cell patch-clamp recordings of rat midbrain dopaminergic neurons isolate a sulphonylurea- and ATP-sensitive component of potassium currents activated by hypoxia. J Neurophysiol 79:1239-1245.

Hanley JJ, Bolam JP (1997) Synaptology of the nigrostriatal projection in relation to the compartmental organization of the neostriatum in the rat. Neuroscience 81:353-370.

Häusser MA, de Weille JR, Lazdunski M (1991) Activation by cromakalim of pre- and post-synaptic ATP-sensitive $\mathrm{K}^{+}$channels in substantia nigra. Biochem Biophys Res Commun 174:909-914.

Hung HC, Lee EH (1998) MPTP produces differential oxidative stress and antioxidative responses in the nigrostriatal and mesolimbic dopaminergic pathways. Free Radic Biol Med 24:76-84.

Ichinari K, Kakei M, Matsuoka T, Nakashima H, Tanaka H (1996) Direct activation of the ATP-sensitive potassium channel by oxygen free radicals in guinea-pig ventricular cells: its potentiation by MgADP. J Mol Cell Cardiol 28:1867-1877.

Inagaki N, Gonoi T, Clement JP, Wang CZ, Aguilar-Bryan L, Bryan J, Seino S (1996) A family of sulfonylurea receptors determines the pharmacological properties of ATP-sensitive $\mathrm{K}^{+}$channels. Neuron 16:1011-1017.

Isomoto S, Kondo C, Yamada M, Matsumoto S, Higashiguchi O, Horio Y, Matsuzawa Y, Kurachi Y (1996) A novel sulfonylurea receptor forms with BIR (Kir6.2) a smooth muscle type ATP-sensitive $\mathrm{K}^{+}$channel. J Biol Chem 271:24321-24324.

Jiang C, Sigworth FJ, Haddad GG (1994) Oxygen deprivation activates an ATP-inhibitable $\mathrm{K}^{+}$channel in substantia nigra neurons. J Neurosci 14:5590-5602.

Kamsler A, Segal M (2004) Hydrogen peroxide as a diffusible signal molecule in synaptic plasticity. Mol Neurobiol 29:167-178.

Kang Y, Kitai ST (1993) Calcium spike underlying rhythmic firing in dopaminergic neurons of the rat substantia nigra. Neurosci Res 18:195-207.

Koós T, Tepper JM (1999) Inhibitory control of neostriatal projection neurons by GABAergic interneurons. Nat Neurosci 2:467-472.

Krippeit-Drews P, Kramer C, Welker S, Lang F, Ammon HPT, Drews G (1999) Interference of $\mathrm{H}_{2} \mathrm{O}_{2}$ with stimulus-secretion coupling in mouse pancreatic $\beta$-cells. J Physiol (Lond) 514:471-481.

Lee K, Dixon AK, Freeman TC, Richardson PJ (1998) Identification of an ATP-sensitive potassium channel current in rat striatal cholinergic interneurones. J Physiol (Lond) 510:441-453.

Levesque D, Greenfield SA (1991) Psychopharmacological evidence for a role of the ATP-sensitive potassium channel in the substantia nigra of the rat. Neuropharmacology 30:359-365.

Liss B, Bruns R, Roeper J (1999) Alternative sulfonylurea receptor expression defines sensitivity to K-ATP channels in dopaminergic midbrain neurons. EMBO J 18:833-846.

Liu Y, Fiskum G, Schubert D (2002) Generation of reactive oxygen species by the mitochondrial electron transport chain. J Neurochem 80:780-787.

Mercuri NB, Bonci A, Johnson SW, Stratta F, Calabresi P, Bernardi G (1994) Effects of anoxia on rat midbrain dopamine neurons. J Neurophysiol 71:1165-1173.

Mourre C, Ben Ari Y, Bernardi H, Fosset M, Lazdunski M (1989) Antidiabetic sulfonylureas: localization of binding sites in the brain and effects on the hyperpolarization induced by anoxia in hippocampal slices. Brain Res 486:159-164

Murphy KP, Greenfield SA (1992) Neuronal selectivity of ATP-sensitive potassium channels in guinea-pig substantia nigra revealed by responses to anoxia. J Physiol (Lond) 453:167-183.

Neuhoff H, Neu A, Liss B, Roeper J (2002) $I_{\mathrm{h}}$ channels contribute to the different functional properties of identified dopaminergic subpopulations in the midbrain. J Neurosci 22:1290-1302.

Nishida M, Maruyama Y, Tanaka R, Kontani K, Nagao T, Kurose H (2000) G $\alpha_{i}$ and $\mathrm{G} \alpha_{\mathrm{o}}$ are target proteins of reactive oxygen species. Nature 408:492-495.
Noma A (1983) ATP-regulated $\mathrm{K}^{+}$channels in cardiac muscle. Nature 305:147-148.

Olanow CW, Tatton WG (1999) Etiology and pathogenesis of Parkinson's disease. Annu Rev Neurosci 22:123-144.

Oyama Y, Hayashi A, Ueha T, Maekawa K (1994) Characterization of 2', $7^{\prime}$ dichlorofluorescin fluorescence in dissociated mammalian brain neurons: estimation on intracellular content of hydrogen peroxide. Brain Res 635:113-117.

Paladini CA, Iribe Y, Tepper JM (1999) GABA $_{A}$ receptor stimulation blocks NMDA-induced bursting of dopaminergic neurons in vitro by decreasing input resistance. Brain Res 832:145-151.

Prensa L, Parent A (2001) The nigrostriatal pathway in the rat: a single-axon study of the relationship between dorsal and ventral tier nigral neurons and the striosome/matrix striatal compartments. J Neurosci 21:7247-7260.

Rae J, Cooper K, Gates P, Watsky M (1991) Low access resistance perforated patch recordings using amphotericin B. J Neurosci Methods 37:15-26.

Reynolds IJ, Hastings TG (1995) Glutamate induces the production of reactive oxygen species in cultured forebrain neurons following NMDA receptor activation. J Neurosci 15:3318-3327.

Rice ME, Cragg SJ, Greenfield SA (1997) Characteristics of electrically evoked somatodendritic dopamine release in substantia nigra and ventral tegmental area in vitro. J Neurophysiol 77:853-862.

Roeper J, Ashcroft FM (1995) Metabolic inhibition and low internal ATP activate K-ATP channels in rat dopaminergic substantia nigra neurones. Pflügers Arch 430:44-54.

Sah R, Schwartz-Bloom RD (1999) Optical imaging reveals elevated intracellular chloride in hippocampal pyramidal cells after oxidative stress. J Neurosci 19:9209-9217.

Schaffer P, Pelzmann B, Bernhart E, Lang P, Machler H, Rigler B, Koidl B (1999) The sulphonylurea glibenclamide inhibits voltage dependent potassium currents in human atrial and ventricular myocytes. Br J Pharmacol 128:1175-1180.

Scuvee-Moreau J, Seutin V, Vrijens B, Pirotte B, De Tullio P, Massotte L, Albert A, Delarge J, Dresse A (1997) Effect of potassium channel openers on the firing rate of hippocampal pyramidal cells and A10 dopaminergic neurons in vitro. Arch Physiol Biochem 105:421-428.

Seutin V, Scuvee-Moreau J, Masotte L, Dresse A (1995) Hydrogen peroxide hyperpolarizes rat CA1 pyramidal neurons by inducing an increase in potassium conductance. Brain Res 683:275-278.

Stanford IM, Lacey MG (1995) Regulation of a potassium conductance in rat midbrain dopamine neurons by intracellular adenosine triphosphate (ATP) and the sulfonylureas tolbutamide and glibenclamide. J Neurosci 15:4651-4657.

Sundaresan M, Yu ZX, Ferrans VJ, Irani K, Finkel T (1995) Requirement for generation of $\mathrm{H}_{2} \mathrm{O}_{2}$ for platelet-derived growth factor signal transduction. Science 270:296-299.

Tokube K, Kiyosue T, Arita M (1998) Effects of hydroxyl radicals on $\mathrm{K}_{\mathrm{ATP}}$ channels in guinea-pig ventricular myocytes. Pflügers Arch 437:155-157.

Trépanier G, Furling D, Puymirat J, Mirault ME (1996) Immunocytochemical localization of seleno-glutathione peroxidase in the adult mouse brain. Neuroscience 75:231-243.

Wilson CJ, Callaway JC (2000) Coupled oscillator model of the dopaminergic neuron of the substantia nigra. J Neurophysiol 83:3084-3100.

Witkovsky P, Gabriel R, Haycock JW, Meller E (2000) Influence of light and neural circuitry on tyrosine hydroxylase phosphorylation in the rat retina. J Chem Neuroanat 19:105-116.

Xia Y, Haddad GG (1991) Major differences in CNS sulfonylurea receptor distribution between the rat (newborn, adult) and turtle. J Comp Neurol 314:278-289.

Yung WH, Häusser MA, Jack JJ (1991) Electrophysiology of dopaminergic and non-dopaminergic neurones of the guinea-pig substantia nigra pars compacta in vitro. J Physiol (Lond) 436:643-667.

Zini S, Tremblay E, Pollard H, Moreau J, Ben-Ari Y (1993) Regional distribution of sulfonylurea receptors in the brain of rodent and primate. Neuroscience 55:1085-1091. 